\title{
Erratum to: Special issue on clubroot and blackleg diseases of brassicas - foreword
}

\author{
Elke Diederichsen • Geoffrey R. Dixon • Ann-Charlotte Wallenhammar • Dilantha Fernando • \\ Marie-Hélène Balesdent
}

Published online: 22 July 2016

C Koninklijke Nederlandse Planteziektenkundige Vereniging 2016

\section{Erratum to: Eur J Plant Pathol DOI 10.1007/s10658-016-0963-1}

Address of Dr. Dixon needs to be correct as Prof. Geoffrey R. Dixon

Managing Director, GreenGene International Hill Rising, Horsecastles Lane, Sherborne, Dorset DT9 6BH.

United Kingdom

Visiting Professor in the Department of Agriculture, Policy \& Development, at the University of Reading, United Kingdom.

The online version of the original article can be found at http://dx. doi.org/10.1007/s10658-016-0963-1

\section{E. Diederichsen $(\triangle)$}

Institut für Biologie - Angewandte Genetik, Freie Universität

Berlin, Albrecht-Thaer-Weg 6, D-14195 Berlin, Germany

e-mail: elked@zedat.fu-berlin.de

\section{G. R. Dixon}

GreenGene International Hill Rising, Horsecastles Lane, Sherborne, Dorset DT9 6BH, UK

\section{G. R. Dixon}

Department of Agriculture, Policy \& Development, University of Reading, Reading, UK

\section{A.-C. Wallenhammar}

Rural Economy and Agricultural Society, HS Konsult AB, Box, 271, SE, /01 45 Örebro, Sweden
A.-C. Wallenhammar

Department of Soil and Environment, Swedish University of Agricultural Sciences, Skara, Sweden

D. Fernando

Deprtmant of Plant Science, University of Manitoba, R3T 2N2, Winnipeg, MB, Canada

M.-H. Balesdent UMR BIOGER, INRA, AgroParisTech, Université Paris-Saclay, 78850 Thiverval-Grignon, France 